\author{
Anna Weronika Brzezińska \\ Instytut Etnologii i Antropologii Kulturowej \\ Wydział Historyczny \\ Uniwersytet im. Adama Mickiewicza w Poznaniu
}

\title{
W pięciolecie ratyfikacji przez Polskę Konwencji UNESCO z 2003 roku w sprawie ochrony niematerialnego dziedzictwa kulturowego
}

\begin{abstract}
Streszczenie: Konwencja UNESCO z 2003 roku w sprawie ochrony niematerialnego dziedzictwa kulturowego została ratyfikowana przez Polskę w 2011 roku. Od tego czasu podejmowane są liczne działania na rzecz upowszechnienia wiedzy o Konwencji, jej celach i możliwościach promowania wiedzy dotyczącej dziedzictwa kulturowego. W Polsce wdrażaniem jej postulatów zajmuje się Ministerstwo Kultury i Dziedzictwa Narodowego oraz Narodowy Instytut Dziedzictwa. W działania aktywnie włączają się przedstawiciele organizacji pozarządowych, w tym członkinie i członkowie Polskiego Towarzystwa Ludoznawczego. Artykuł omawia okoliczności wprowadzenia Konwencji w Polsce oraz charakteryzuje główne działania na rzecz jej upowszechniania.
\end{abstract}

Słowa klucze: Konwencja UNESCO, niematerialne dziedzictwo kulturowe, społeczność lokalna, upowszechnianie kultury

\section{On the Fifth Anniversary of Ratification of 2003 UNESCO Convention for the Safeguarding of Intangible Cultural Heritage by Poland}

Summary: The UNESCO Convention for the Safeguarding of the Intangible Cultural Heritage from 2003 was ratified by Poland in 2011. Since then numerous activities have been undertaken to popularise the knowledge of the Convention, its objectives and opportunities of promoting knowledge referring to cultural heritage. In Poland, the Ministry of Culture and National Heritage and the National Heritage Institute are engaged in implementing its postulates. Members of non-governmental organizations, including members of the Polish Ethnological Society, actively participate in these activities. The article discusses circumstances accompanying the introduction of the Convention in Poland and characterizes main activities for its popularisation.

Key words: UNESCO Convention, intangible cultural heritage, local community, culture popularisation 


\section{Wprowadzenie}

W 2016 roku mija pięć lat od czasu ratyfikowania przez Polskę Konwencji w sprawie ochrony niematerialnego dziedzictwa kulturowego z 2003 roku. Według definicji zawartej w dokumencie niematerialne dziedzictwo kulturowe obejmuje:

praktyki, wyobrażenia, przekazy, wiedzę i umiejętności - jak również związane z nimi instrumenty, przedmioty, artefakty i przestrzeń kulturową - które wspólnoty, grupy i, w niektórych przypadkach, jednostki uznają za część własnego dziedzictwa kulturowego. To niematerialne dziedzictwo kulturowe, przekazywane z pokolenia na pokolenie, jest stale odtwarzane przez wspólnoty i grupy w relacji z ich otoczeniem, oddziaływaniem przyrody i ich historią oraz zapewnia im poczucie tożsamości i ciągłości, przyczyniając się w ten sposób do wzrostu poszanowania dla różnorodności kulturowej oraz ludzkiej kreatywności [Konwencja... 2003].

Jest zatem okazja do tego, by podsumować prace podejmowane na rzecz upowszechniania wiedzy o idei Konwencji w ciągu ostatnich pięciu lat. Polskie Towarzystwo Ludoznawcze aktywnie włączało się w działania, a jego członkinie i członkowie uczestniczyli w konferencjach naukowych oraz konsultacjach odbywających się w regionach. Są też organizatorami wystaw i warsztatów promujących idee ochrony niematerialnego dziedzictwa kulturowego.

Momentem ważnym dla rozpropagowania wiedzy o Konwencji był Rok Oskara Kolberga, obchodzony w Polsce w 2014 roku w przypadającą wówczas dwusetną rocznicę urodzin etnografa i folklorysty, którego dorobek nadal stanowi punkt odniesienia dla podejmowanych współcześnie badań naukowych. Rok Oskara Kolberga został ustanowiony uchwałą Sejmu III RP 6 grudnia 2013 roku, odbywał się także pod auspicjami UNESCO. Stosowna uchwała została podjęta na 37. Sesji Konferencji Generalnej Organizacji Narodów Zjednoczonych do spraw Oświaty, Nauki i Kultury. Postać patrona okazała się być dobrym pretekstem do tego, by w środowiskach lokalnych upowszechniać idee Konwencji i niematerialnego dziedzictwa kulturowego. Polskie Towarzystwo Ludoznawcze, będące współorganizatorem obchodów roku Kolbergowskiego, aktywnie uczest- 
niczy we wszelkich działaniach związanych z Konwencją. Pewnego rodzaju podsumowaniem jest i prezentowany kolejny tom „Łódzkich Studiów Etnograficznych", w którym zebrane zostały artykuły przygotowane przez specjalistów związanych z różnymi instytucjami naukowymi i kulturalnymi, a także z organizacjami pozarządowymi. Reprezentują oni kilka dyscyplin naukowych (etnologia, językoznawstwo, folklorystyka, muzealnictwo), prowadzą własne badania w tym zakresie, posługując się odmiennym i oryginalnym spojrzeniem na opisywane zjawisko. Czytelnik zyskuje zatem nie tylko dostęp do katalogu zjawisk, ale i do sposobów ich opisywania i interpretowania. Warto w tym momencie przypomnieć okoliczności powstania samej Konwencji oraz początki jej wdrażania i upowszechniania w Polsce, by dokonać podsumowania dotychczasowych działań.

\section{Okoliczności powstania Konwencji UNESCO z 2003 roku}

Konwencja UNESCO w sprawie ochrony niematerialnego dziedzictwa kulturowego została przyjęta 17 października 2003 roku podczas Konferencji Generalnej Organizacji Narodów Zjednoczonych do spraw Oświaty, Nauki i Kultury, odbywającej się w Paryżu. Efektem działań podejmowanych w ramach jej założeń ma być stworzenie „żywej mapy”, która pokazywałaby zróżnicowanie kulturowe świata z jednoczesnym wzbudzaniem refleksji nad samą istotą niematerialnego dziedzictwa kulturowego. Co ważne, mają to być tradycje nadal kultywowane w środowiskach i przez same środowiska, z jak najmniejszą ingerencją instytucji zewnętrznych [Ratajski 2013: 23].

Powstanie tej Konwencji było poprzedzone licznymi działaniami i wcześniejszymi traktatami międzynarodowymi poświęconymi różnym aspektom dziedzictwa, by wymienić najważniejszy z nich - Konwencję o ochronie dziedzictwa kulturowego i naturalnego z 1972 roku. Kładła ona jednak nacisk przede wszystkim na materialny aspekt dziedzictwa, stąd pojawiały się z czasem kolejne dokumenty podkreślające bardziej aspekt niematerialny i społeczny, który obejmował znacznie więcej zjawisk kulturowych wartych uwagi i ochrony. W 1989 roku opracowane zostały Zalecenia dotyczące ochrony kultury tradycyjnej i ludowej (ang. Recommendation on the Safeguarding of Traditional Culture and Folklore) i to 
one stały się bezpośrednią przyczyną do podjęcia opracowania tekstu osobnego dokumentu, w którym podkreślony zostałby i niematerialny charakter dziedzictwa (ang. Intangible Cultural Heritage).

Ważnym elementem polityki UNESCO są nie tylko traktaty międzynarodowe, ale i programy opracowywane z myślą o poszczególnych elementach dziedzictwa kulturowego. Dla interesującej nas Konwencji jest ich kilka, w bezpośredni sposób nawiązujących do idei ochrony niematerialnego dziedzictwa: Tradycyjna muzyka świata (ogłoszony w 1961 roku, efekt współpracy UNESCO z Międzynarodową Radą Muzyki), Zagrożone języki (lata osiemdziesiąte XX wieku), Pamięć Świata¹ (1992 rok) oraz Żywe skarby kultury (1990 rok). Natomiast działaniem, którego następstwem było ostateczne przygotowanie treści Konwencji, stało się opracowanie Listy Arcydzieł Ustnego i Niematerialnego Dziedzictwa Ludzkości [Schreiber 2005: 8-10]. Warto też dodać, że od momentu uchwalenia Konwencji już nie są ogłaszane nowe listy i tym samym przyjęto, że Konwencja z 2003 roku ma za zadanie chronić wszystkie aspekty i przejawy niematerialnego dziedzictwa.

Obecnie w ramach samej Konwencji prowadzone są trzy międzynarodowe spisy zjawisk: (1) Lista niematerialnego dziedzictwa kulturowego wymagającego pilnej ochrony; (2) Lista reprezentatywna niematerialnego dziedzictwa kulturowego oraz (3) Rejestr programów, projektów i działań mających na celu ochronę niematerialnego dziedzictwa kulturowego (nazywany Rejestrem Najlepszych Praktyk). Zjawiska ubiegające się o wpis na daną listę muszą przede wszystkim dotyczyć tych przejawów kultury, które są istotne dla ich nosicieli, być emanacją ich tożsamości oraz być przekazywane następnym pokoleniom. Nadrzędna jest zatem wola i chęć samych depozytariuszy niematerialnego dziedzictwa kultury, by podejmować działania na rzecz ochrony i upowszechniania elementów własnego dziedzictwa kulturowego. By dane zjawisko mogło znaleźć się na liście światowej, musi wpierw być zarejestrowane na listach krajowych tych państw, które Konwencję ratyfikowały.

1 Aktualnie Lista obejmuje 238 dokumentów, a polskie dziedzictwo reprezentuje 9 wpisów. Więcej na temat programu: http://www.unesco.pl/komunikacja-i-informacja/pamiec-swiata/. 


\section{Ratyfikacja Konwencji przez Polskę}

Do roku 2016 Konwencja została ratyfikowana przez 168 krajów, które w dokumentach określane są mianem „państwa - strony”. Polska była 135 krajem, który podpisując ten akt prawa międzynarodowego, podjął się zbudować krajowy system ochrony niematerialnego dziedzictwa zgodny z polskim prawem. Poprzedzone to było pracami zespołów ekspertów, które dotyczyły przede wszystkim tłumaczenia tekstu samej Konwencji na język polski, ale i szeroko zakrojonych konsultacji prawno-organizacyjnych. Ze strony państwa instytucją odpowiedzialną za realizację jej postulatów jest Ministerstwo Kultury i Dziedzictwa Narodowego, a koordynatorem prac odpowiedzialnych za skonstruowanie między innymi krajowej listy jest Narodowy Instytut Dziedzictwa.

Ważnym wydarzeniem, rozpoczynającym środowiskowe konsultacje, było zorganizowanie debaty 20 września 2011 roku na zaproszenie ówczesnego Prezydenta RP - Bronisława Komorowskiego. W ramach Forum Debaty Publicznej, w obszarze Twórczość, dziedzictwo kulturowe i przyrodnicze bogactwem Polski zaproszeni goście - naukowcy i praktycy - dyskutowali nad problematyką identyfikacji dziedzictwa niematerialnego. Jednym z dyskutantów był prezes Polskiego Towarzystwa Ludoznawczego - prof. dr hab. Michał Buchowski [Brzezińska 2013: 114].

Od ratyfikacji Konwencji do ogłoszenia Krajowej listy niematerialnego dziedzictwa kulturowego minęły dwa lata. W tym czasie odbyło się wiele ważnych wydarzeń naukowych, w organizację których angażowani byli także członkowie Polskiego Towarzystwa Ludoznawczego. Były to konferencje naukowe, których efektem są między innymi dwa tomy wydane w specjalnie powołanej serii Niematerialne dziedzictwo kulturowe w Polsce i jego ochrona [Niematerialne dziedzictwo kulturowe: zakresy... 2013; Niematerialne dziedzictwo kulturowe: źródła... 2015] oraz konsultacje społeczne dla ekspertów związanych z instytucjami kultury i organizacjami pozarządowymi.

Pierwsza edycja konsultacji społecznych w formie warsztatów odbyła się 18 czerwca 2012 roku w Warszawie, ich organizatorami byli Polskie Towarzystwo Ludoznawcze, Narodowy Instytut Dziedzictwa, Stowarzyszenie Twórców Ludowych oraz Instytut Stosunków Międzynarodowych 
Uniwersytetu Warszawskiego. Druga edycja miała miejsce w dniach 25-26 października 2012 roku w Lublinie, a do grona współorganizatorów dołączył Instytut Kulturoznawstwa Uniwersytetu Marii Curie-Skłodowskiej. Każdorazowo brało w nich udział kilkadziesiąt osób z całej Polski, reprezentujących różne regiony, instytucje i organizacje pozarządowe [Brzezińska, Schreiber, Smyk 2013: 353-367]. Wspólnie wypracowane wnioski zostały przekazane Narodowemu Instytutowi Dziedzictwa, wiele z nich zostało uwzględnionych w projektowanym krajowym systemie ochrony.

Efektem prac przygotowawczych było uroczyste ogłoszenie 15 stycznia 2013 roku uruchomienia Krajowej listy niematerialnego dziedzictwa kulturowego. Podczas zorganizowanej w Olsztynie konferencji prasowej, z udziałem ówczesnego Wiceministra Kultury i Dziedzictwa Narodowego - Piotra Żuchowskiego oraz Marszałka Województwa WarmińskoMazurskiego - Jacka Protasa, obecni byli także przedstawiciele licznych organizacji pozarządowych, które angażowały się we wcześniejsze prace przygotowawcze. Nieprzypadkowy był też wybór Olsztyna jako miejsca ogłoszenia uruchomienia listy krajowej. Samorząd województwa warmińsko-mazurskiego jako pierwszy utworzył osobne stanowisko pracy dla urzędnika, który miałby zajmować się tylko i wyłącznie prowadzeniem rejestru zjawisk z zakresu niematerialnego dziedzictwa kulturowego na terenie województwa.

\section{Krajowa lista niematerialnego dziedzictwa kulturowego}

Integralnym elementem krajowego systemu ochrony niematerialnego dziedzictwa kulturowego jest prowadzenie rejestru zjawisk. Centralną bazę prowadzi Narodowy Instytutu Dziedzictwa, który na stronach serwisu internetowego [ww.niematerialne.nid.pl] publikuje aktualną listę zawierającą szczegółowy opis danego zjawiska, jego historię oraz stan aktualny. Jak czytamy na stronach NID:

Krajowa lista niematerialnego dziedzictwa kulturowego jest spisem przejawów żywego dziedzictwa niematerialnego z terenu Polski. Lista ma charakter wyłącznie informacyjny i zawiera opis zamieszczonych na niej zjawisk, ich rys historyczny, informacje o miejscu występowania, znaczeniu dla 
praktykujących je społeczności, a także materiały fotograficzne [http://niematerialne.nid.pl/Dziedzictwo_niematerialne/Krajowa_inwentaryzacja/].

Wszystkie zjawiska ubiegające się o wpis muszą spełniać kilka kryteriów oraz przejawiać się w dziedzinach określonych przez Konwencję, a są to: (1) tradycje i przekazy ustne, w tym język jako nośnik niematerialnego dziedzictwa kulturowego; (2) sztuki widowiskowe; (3) zwyczaje, rytuały i obrzędy świąteczne; (4) wiedza i praktyki dotyczące przyrody i wszechświata; (5) umiejętności związane z rzemiosłem tradycyjnym. Wniosek przygotowywany w oparciu o dostępny formularz muszą poprzedzić konsultacje społeczne, których celem jest nade wszystko uniknięcie konfliktów i napięć w środowiskach lokalnych. Wszak UNESCO promuje idee szeroko pojętego dialogu, a przedsięwzięcia podejmowane na rzecz ochrony wybranych elementów mają społeczności integrować i zachęcać do wspólnych działań, a nie antagonizować.

W poczynaniach na rzecz budowy krajowego rejestru zjawisk Narodowy Instytut Dziedzictwa wspierany jest przez Radę ds. niematerialnego dziedzictwa kulturowego, która została powołana decyzją Ministra Kultury i Dziedzictwa Narodowego. Stanowi ona jednocześnie organ doradczy. Jej zadaniem jest:

opiniowanie na rzecz Ministra KiDN wniosków o wpis na Krajowa listę niematerialnego dziedzictwa kulturowego, rekomendowanie rozwiązań systemowych, rekomendowanie propozycji elementów do wpisu na Listy Konwencji UNESCO, rekomendowanie priorytetów w ochronie dziedzictwa niematerialnego [http://niematerialne.nid.pl/Ochrona_dziedzictwa/ system_ochrony_w_Polsce/struktura_administracyjna/].

Obecnie w Radzie zasiada 20 osób² reprezentujących instytucje naukowe i instytucje kultury z całego kraju oraz organizacje pozarządowe, w tym Polskie Towarzystwo Ludoznawcze. Każdorazowo członkowie Rady zapoznają się z wnioskami przygotowanymi przez depozytariuszy

2 Pełen skład Rady: http://niematerialne.nid.pl/Ochrona_dziedzictwa/system_ochrony_w_Polsce/struktura_administracyjna/. 
niematerialnego dziedzictwa kulturowego, a w oparciu o tak przygotowane rekomendacje minister podejmuje decyzję o umieszczeniu lub nie na liście danego zjawiska.

Wnioskodawcami ubiegającymi się o wpis na listę są przede wszystkim organizacje pozarządowe funkcjonujące w środowiskach lokalnych, których członkowie są bezpośrednimi spadkobiercami lokalnych tradycji oraz stowarzyszenia osób skupionych wokół idei upowszechniania w różnych środowiskach treści kultury. Według obecnie obowiązującej procedury, beneficjenci we wniosku składanym do Narodowego Instytutu Dziedzictwa zawierają nie tylko opis zjawiska, ale też przygotowują plan dalszej, celowej już ochrony danego zjawiska. Duży nacisk jest kładziony na te formy upowszechniania, w których uczestniczą najmłodsi przedstawiciele danych społeczności, często we współpracy z instytucjami kultury i oświaty. Wspólne opracowywanie strategii ochrony zgłaszanego elementu już samo w sobie jest pierwszym etapem ochrony i wymaga od członków danej społeczności namysłu i refleksji nad tym, czym taka ochrona powinna być i komu ma służyć. Nade wszystko działania te mają angażować w jak najszerszy sposób członków społeczności lokalnej i doceniać inicjatywy oddolne.

Krajowa lista niematerialnego dziedzictwa kulturowego, którą prowadzi Narodowy Instytut Dziedzictwa liczy obecnie 17 pozycji (patrz Tabela 1). Uroczyste wręczenie nominacji po raz pierwszy odbyło się w 2014 roku na Zamku Królewskim w Warszawie z udziałem ówczesnej Ministry Kultury i Dziedzictwa Narodowego, prof. dr hab. Małgorzaty Omilanowskiej. Znalezienie się na Krajowej liście niematerialnego dziedzictwa kulturowego jest wśród depozytariuszy tego dziedzictwa postrzegane jako niezwykle nobilitujące. Tak naprawdę jest dopiero początkiem drogi do rzeczywistej ochrony niematerialnego dziedzictwa kulturowego i realizacji założonych we wnioskach działań. W jaki sposób krajowa lista będzie miała realny wpływ na rzeczywisty stan świadomości co do wartości zjawisk objętych ochroną w myśl Konwencji? Odpowiedź na to pytanie przyniosą lata następne, kiedy będą realizowane projekty edukacyjne i promujące lokalne dziedzictwo kulturowe. 
Tabela 1. Krajowa lista niematerialnego dziedzictwa kulturowego w 2016 roku $^{3}$

\begin{tabular}{|c|c|c|}
\hline L.p. & Nazwa zjawiska & Województwo \\
\hline 1 & $\begin{array}{c}\text { Rusznikarstwo artystyczne i historyczne - } \\
\text { wyroby według tradycyjnej szkoły cieszyńskiej }\end{array}$ & Śląskie \\
\hline 2 & Szopkarstwo krakowskie & Małopolskie \\
\hline 3 & Pochód Lajkonika & Małopolskie \\
\hline 4 & Flisackie tradycje w Ulanowie & Podkarpackie \\
\hline 5 & Procesja Bożego Ciała w Łowiczu & Łódzkie \\
\hline 6 & Język esperanto jako nośnik kultury esperanckiej & Wpis ogólnopolski \\
\hline 7 & $\begin{array}{c}\text { Umiejętność wytwarzania instrumentu i gry na } \\
\text { kozie (dudach podhalańskich) }\end{array}$ & Małopolskie \\
\hline 8 & Hafciarstwo kaszubskie szkoły żukowskiej & Pomorskie \\
\hline 9 & Sokolnictwo - żywa tradycja & Wpis ogólnopolski \\
\hline 10 & Polskie tańce narodowe - polonez, mazur, & Wpis ogólnopolski \\
\hline 11 & kujawiak, oberek, krakowiak & Wielkopolska \\
\hline 12 & $\begin{array}{c}\text { Tradycyjna technika ludwisarska Felczyńskich } \\
\text { w Taciszowie }\end{array}$ & Śląskie \\
\hline 13 & Przywołówki dyngusowe w Szymborzu & Kujawsko-pomorskie \\
\hline 14 & Gwara warmińska jako nośnik tradycji ustnych & Warmińsko-mazurskie \\
\hline 15 & Zabawkarstwo żywiecko-suskie & Śląskie \\
\hline 16 & Bartnictwo & Podlaskie \\
\hline 17 & Perebory - nadbużańskie tradycje tkackie & Lubelskie \\
\hline
\end{tabular}

3 http://niematerialne.nid.pl/Dziedzictwo_niematerialne/Krajowa_inwentaryzacja/Krajowa_lista_NDK/ 


\section{Popularyzacja idei ochrony}

\section{niematerialnego dziedzictwa kulturowego}

Niematerialne dziedzictwo kulturowe stało się tematem wielu projektów naukowych, których efektem są liczne publikacje. Coraz częściej badania te są prowadzone we współpracy ze społecznościami lokalnymi, które same poszukują kontaktów z instytucjami naukowymi, proponując współpracę w zakresie inwentaryzacji zjawisk z zakresu niematerialnego dziedzictwa kulturowego. Przykładem są badania prowadzone przez Polskie Towarzystwo Ludoznawcze w latach 2013-2015 dotyczące rzemiosł: hafciarstwa [www.snutki2013.blogspot.com], tkactwa [www.perebory2013. blogspot.com] oraz koronczarstwa [www.klocki2014.blogspot.com]. Jest to też okazją do bezpośredniego kontaktu z depozytariuszami niematerialnego dziedzictwa kulturowego i informowania ich o ideach Konwencji. Przywołane badania były podstawą do przygotowania dwóch wniosków o wpis na Krajową listę, z których jeden (perebory - nadbużańskie tradycje tkackie) [patrz: Tabela 1, pozycja nr 17] został już na niej umieszczony. Drugi wniosek (koronka klockowa z Bobowej) jest w przygotowaniu.

Osobną grupę stanowią studia dotyczące wytworzenia aparatu pojęciowego, związane z tłumaczeniem samej Konwencji na język polski, a także z dostosowaniem pojęć i terminów stosowanych na gruncie polskich badań nad dziedzictwem kulturowym. Termin „niematerialne dziedzictwo kulturowe" jest odpowiednikiem angielskiego intangible, co dosłownie należałoby przetłumaczyć jako nieuchwytne, ulotne. W polskiej tradycji nauk o kulturze nie istnieje takie pojęcie, stąd decyzja o wprowadzeniu określenia „niematerialne dziedzictwo kulturowe”. Stosowane jest ono zamiast dotychczas funkcjonujących i ugruntowanych w polskiej nauce określeń „folklor i tradycja” [Jasiewicz 2013: 54-56]. Podobne zastrzeżenia budzi określenie „wspólnota” zamiast „społeczność lokalna” (ang. community), które znajdujemy w tekście Konwencji [Jodełka 2005: 176].

Jednym z ważniejszych celów inicjatyw związanych z budowaniem krajowego systemu ochrony niematerialnego dziedzictwa kulturowego, są przedsięwzięcia o charakterze edukacyjnym. Dużą rolę odegrały w nich organizacje pozarządowe, szczególnie aktywne Forum Muzyki Tradycyjnej, które znakomicie wykorzystało możliwości dotarcia zarówno do nauczy- 
cieli, jak i do edukatorów nieformalnych. W trakcie trwania Roku Kolberga uruchomionych zostało kilka portali edukacyjnych wraz z dostępną bazą wiedzy pod postacią publikacji, nagrań video i audio. Działania te skierowane początkowo tylko na edukację muzyczną, stopniowo rozszerzały się i na inne dziedziny. Największym dorobkiem jest uruchomienie programu Mały Kolberg, którego celem jest przede wszystkim aktywizacja osób ze środowisk, w których jest utrudniony dostęp do kultury. W każdym z tych działań edukacja na temat Konwencji i jej treści odgrywa istotną rolę [http:// www.akademiakolberga.pl/project/malykolberg/].

Ważnym krokiem było w roku 2016 uruchomienie przez Ministerstwo Kultury i Dziedzictwa Narodowego w ramach istniejącego programu Dziedzictwo kulturowe - kultura ludowa i tradycyjna specjalnego priorytetu o charakterze pilotażowym. Jego cele zostały określone w następujący sposób:

wspieranie procesu transmisji w obrębie danej wspólnoty kulturowej, przejawiającego się w bezpośrednim przekazie wiedzy, umiejętności, funkcji - ze szczególnym naciskiem na ich unikatowość, bądź zagrożenie zanikiem. Istotnym jest przy tym czynnik in situ - przekaz winien odbywać się pomiędzy osobami wywodzącymi się z tej samej wspólnoty i kultury lokalnej, bądź możliwie najbliższej [http://www.mkidn. gov.pl/media/po2016/dokumenty/20151008Dziedzictwo_kulturowepriorytet_3-Kultura_ludowa_i_tradycyjna_2016.pdf]

Program cieszył się dużym zainteresowaniem mistrzów, przyznano 32 stypendia twórcom reprezentującym takie dziedziny rzemiosła, jak hafciarstwo (kaszubskie i cieszyńskie), wytwórstwo koronek (igiełkowych, klockowych), krawiectwo strojów ludowych, tkactwo dwuosnowowe, plecionkarstwo, kowalstwo, garncarstwo, snycerstwo i plastyka obrzędowa. Jeden program stypendialny obejmował flisactwo, a pozostałe są związane z przekazywaniem umiejętności muzycznych (gra na dudach, suce biłgorajskiej, bębnach obręczowych, harmonii pedałowej, cymbałach i skrzypcach) oraz z białym śpiewem ${ }^{4}$. Warunkiem uzyskania rocznego

4 Dane uzyskane od Doroty Ząbkowskiej z Departamentu Narodowych Instytucji Kultury w Ministerstwie Kultury i Dziedzictwa Narodowego. 
dofinansowania była chęć przekazania swojej wiedzy i umiejętności przez mistrzów przedstawicielom młodszych pokoleń, wywodzących się z tych samych społeczności i kręgów kulturowych.

\section{Podsumowanie}

Ratyfikacja przez Polskę Konwencji UNESCO z 2003 roku okazała się być wyzwaniem organizacyjnym dla instytucji odpowiedzialnych za wdrożenie jej postulatów. Ważną rolę odegrało środowisko naukowe, w tym członkowie i członkinie Polskiego Towarzystwa Ludoznawczego. Wszystkie wspomniane wyżej działania na rzecz upowszechniania wiedzy dotyczącej ochrony niematerialnego dziedzictwa kulturowego można podzielić na trzy grupy. Do pierwszej grupy zaliczam prowadzenie badań naukowych dokumentujących procesy transformacji dziedzictwa kulturowego oraz rejestrację zachodzących zmian [Czerwińska 2012; Drożdż 2012; Grozdew-Kołacińska, Wosińska 2012; Pieńczak 2012]. Drugą grupę stanowią studia teoretyczne nad redefinicją takich kluczowych pojęć, jak samo dziedzictwo kulturowe, tradycja, kultura tradycyjna oraz folklor, którym towarzyszą ważne refleksje natury metodologicznej [Mokrzan, Songin-Mokrzan 2012: 5-18]. Ostatnia grupa to działania na rzecz udostępniania wiedzy, edukowanie w zakresie dziedzictwa kulturowego oraz animacja różnych grup odbiorców w oparciu o zgromadzone zasoby wiedzy [Grozdew-Kołacińska 2014].

Ważnym elementem pozostają konsultacje społeczne i docieranie do grup lokalnych, będących bezpośrednimi spadkobiercami lokalnych tradycji kulturowych, i informowanie ich o możliwościach wykorzystania Konwencji dla celów promocyjnych, dokumentacyjnych i edukacyjnych.

Na pewno dużym wyzwaniem dla środowiska naukowego w najbliższym czasie będzie prowadzenie systematycznych i kompleksowych badań nad poszczególnymi zjawiskami, o których wspomina Konwencja. Z tym jest też związana kwestia kształcenia specjalistów, którzy wyposażeni w odpowiednie kompetencje będą potrafili dokumentować zjawiska z zakresu niematerialnego dziedzictwa kulturowego oraz wspomagać społeczności lokalne we wszelkich formach ochrony i edukowania w tym zakresie. Ważną kwestią pozostaje uruchomienie studiów podyplomowych 
lub przygotowanie specjalizacji na studiach etnologicznych, których absolwenci posiadaliby wiedzę i umiejętności prowadzenia badań, konsultacji społecznych oraz opracowywania systemów ochrony niematerialnego dziedzictwa kulturowego.

Mamy nadzieję, że prezentując nasz tom ${ }^{5}$ w całości poświęcony zagadnieniu niematerialności dziedzictwa, także Polskie Towarzystwo Ludoznawcze przyczynia się tym samym do budowania refleksji nad niematerialnym dziedzictwem, w jaki sposób je opisywać i chronić, a wreszcie - w jaki sposób zachęcać kolejne pokolenia do zastanawiania się nad tym, co nas otacza i co stanowi o naszej tożsamości: osobistej, lokalnej i regionalnej.

\section{Bibliografia}

\section{Brzezińska Anna Weronika}

2013: Reifikacja dziedzictwa kulturowego w świetle Konwencji UNESCO z 2003 roku. „Nauka”, nr 1, s. 109-128.

\section{Brzezińska Anna Weronika, Schreiber Hanna, Smyk Katarzyna}

2013: Warsztaty dla ekspertów organizacji pozarządowych i instytucji kultury w sprawie Konwencji UNESCO o ochronie niematerialnego dziedzictwa kulturowego z 2003 roku Lublin, 25-26 października 2012 roku. Sprawozdania. [W:] Niematerialne dziedzictwo kulturowe: źródła - wartości - ochrona. Red. J. Adamowski, K. Smyk, Lublin-Warszawa, s. 353-367.

\section{Czerwińska Kinga}

2012: Umiejętności związane z rzemiosłem tradycyjnym. http://www.ptl.info.

\section{Drożdż Anna} $\mathrm{pl} / ? \mathrm{p}=3224$ [ostatni dostęp: lipiec 2016].

2012: Społeczne zwyczaje, rytuały oraz uroczystości świąteczne. http://www. ptl.info.pl/?p=3224 [ostatni dostęp: lipiec 2016].

5 Podsumowaniem działań podejmowanych przez Towarzystwo jest nie tylko ten tom, ale i wystawa przygotowywana we współpracy z Muzeum Etnograficznym we Wrocławiu (Oddział Muzeum Narodowego) pt. Niematerialne dziedzictwo regionu i skarby europejskiej kultury tradycyjnej, której pomysłodawczynią i kuratorką jest Hanna Golla. 


\section{Grozdew-Kołacińska Weronika}

2014: Cele „Raportu”. [W:] Raport o stanie tradycyjnej kultury muzycznej. Red. W. Grozdew-Kołacińska. Warszawa, s. 12-39.

\section{Grozdew-Kołacińska Weronika, Wosińska Małgorzata}

2012: Sztuki widowiskowe. http://www.ptl.info.pl/?p=3224 [ostatni dostęp: lipiec 2016].

\section{Jasiewicz Zbigniew}

2013 Przedmiot i funkcje Konwencji o ochronie niematerialnego dziedzictwa kulturowego. Spojrzenie etnologa. [W:] Niematerialne dziedzictwo kulturowe: źródła - wartości - ochrona. Red. J. Adamowski, K. Smyk. Lublin-Warszawa, s. 51-63.

\section{Konwencja...}

2003: Konwencja UNESCO w sprawie ochrony niematerialnego dziedzictwa kulturowego, sporządzona w Paryżu dnia 17 października 2003 r. [W:] Dziennik Ustaw, 2011, nr 172, poz. 1018.

\section{Mokrzan Michał, Songin-Mokrzan Marta}

2012: $\quad$ Artykulacje lokalności. Konwencja UNESCO dotycząca ochrony niematerialnego dziedzictwa kulturowego jako praktyka dyskursywna. „Zeszyty Etnologii Wrocławskiej”, nr 2 (17), s. 5-18.

Niematerialne dziedzictwo kulturowe: zakresy...

2015: Niematerialne dziedzictwo kulturowe: zakresy-identyfikacje-zagrożenia. Intangible Cultural Heritage: Scope - Identification - Threats. Red. J. Adamowski, K. Smyk. Lublin-Warszawa.

\section{Niematerialne dziedzictwo kulturowe: źródła...}

2013: Niematerialne dziedzictwo kulturowe: źródła - wartości - ochrona: Intangible Cultural Heritage: Origins - Values - Protection. Red. J. Adamowski, K. Smyk. Lublin-Warszawa.

\section{Pieńczak Agnieszka}

2012: Wiedza i praktyki dotyczące przyrody i wszechświata. http://www.ptl. Ratajski Sławomir info.pl/?p=3224 [ostatni dostęp: lipiec 2016].

2013: Koncepcja ochrony dziedzictwa niematerialnego w Konwencji UNESCO. [W:] Niematerialne dziedzictwo kulturowe: źródła - wartości-ochrona. Red. J. Adamowski, K. Smyk. Lublin-Warszawa, s. 21-34.

\section{Schreiber Hanna}

2005: Międzynarodowa ochrona niematerialnego dziedzictwa kulturowego. „Stosunki Międzynarodowe - International Relations”, nr 3-4, s. 169-187. 


\section{Strony internetowe}

http://niematerialne.nid.pl/Dziedzictwo_niematerialne/Krajowa_inwentaryzacja/ [ostatni dostęp: lipiec 2016].

http://niematerialne.nid.pl/Ochrona_dziedzictwa/system_ochrony_w_Polsce/ struktura_administracyjna/ [ostatni dostęp: lipiec 2016].

http://www.unesco.pl/komunikacja-i-informacja/pamiec-swiata/ [ostatni dostęp: lipiec 2016].

http://www.akademiakolberga.pl/project/malykolberg/ [ostatni dostęp: lipiec 2016]. http://www.mkidn.gov.pl/media/po2016/dokumenty/20151008Dziedzictwo_kulturowe-priorytet_3-Kultura_ludowa_i_tradycyjna_2016.pdf [ostatni dostęp: wrzesień 2016].

www.snutki2013.blogspot.com [ostatni dostęp: wrzesień 2016]. www.perebory2013.blogspot.com [ostatni dostęp: wrzesień 2016]. www.klocki2014.blogspot.com [ostatni dostęp: wrzesień 2016]. 